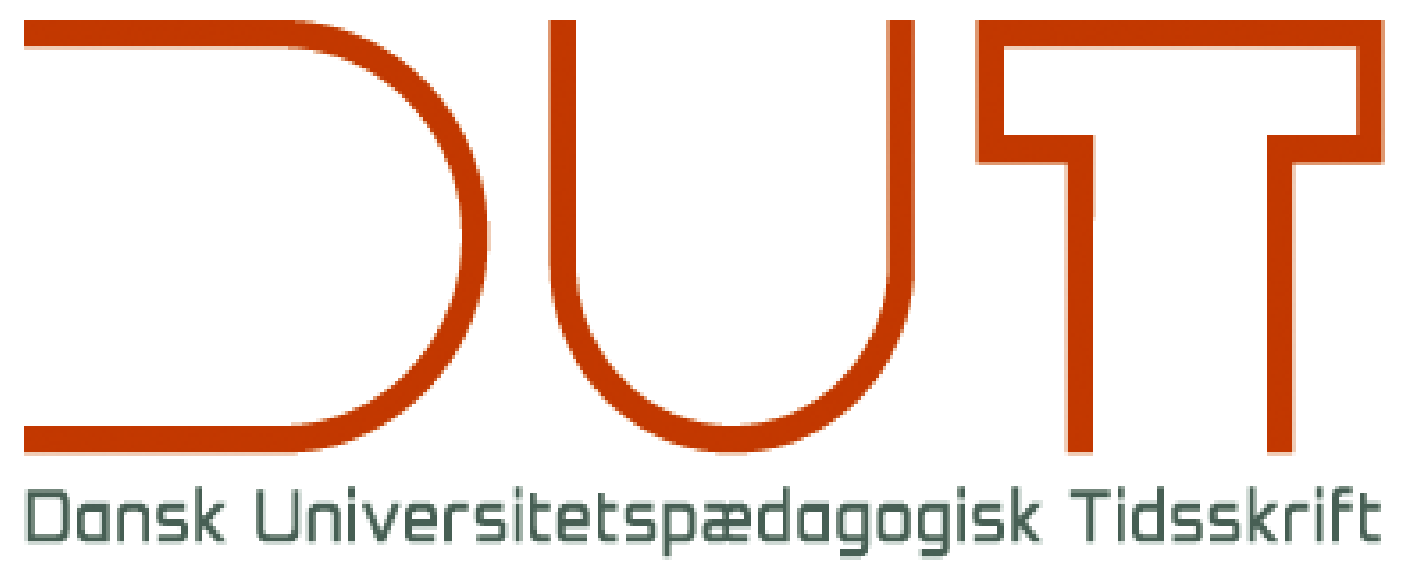

Universitetspædagogikum

Årgang 13 nr. 25 / 2018

Titel

Forfattere

Sidetal

It takes two to tango: The interaction paradox in management education

Lars Esbjerg og Morten Rask

$37-58$

Udgivet af

Dansk Universitetspædagogisk Netværk, DUN

URL

> http://dun-net.dk/

Betingelser for brug af denne artikel

(C) Copyright
Denne artikel er omfattet af ophavsretsloven, og der må citeres fra den. Følgende betingelser skal dog være opfyldt:

- Citatet skal være i overensstemmelse med "god skik"

- Der må kun citeres „i det omfang, som betinges af formålet"

- Ophavsmanden til teksten skal krediteres, og kilden skal angives ift. ovenstående bibliografiske oplysninger.

DUT og artiklens forfatter 


\title{
It takes two to tango: The interaction par- adox in management education
}

\author{
Lars Esbjerg, Associate Professor, Department of Management, Aarhus University \\ Morten Rask, Associate Professor, Department of Management, Aarhus University \\ Practice paper, peer-reviewed
}

In this paper, we argue that we face an interaction paradox in management education. We thus have a situation where students want to talk to their teachers and teachers want to engage in dialogue but neither side seems to get anywhere. Using qualitative and quantitative data from both business school students and teachers, we explore the reasons for this paradox and look for possible solutions. Based on our analysis and interpretation of the data, we propose a conceptual model that shows how feedback is fundamental for effective learning. The conceptual model can be used to understand the interaction paradox. It has implications for both individual teachers and, on an institutional level, for creating conditions conducive for effective feedback and dialogue between students and teachers.

\section{Introduction}

It is our contention that modern management education faces an interaction paradox, where both teachers and students clamour for more interaction and dialogue but both sides are left wanting. On the one side, we have students asking for more feedback on their work, in particular to monitor their individual progress towards meeting the learning goals that they will be tested on during exams. On the other side, we have teachers who want to engage with students in a more meaningful manner than the monologues they often find themselves performing in order to learn how they are doing as teachers and whether students are learning what they should. This is the root of the interaction paradox: that students and teachers are looking for different things when interacting.

In this paper, we strive to understand the paradox from the perspective of both teachers and students - to explore what they want and why they are frustrated. Because students and teachers are not aligned in what they crave, we have to explore related, but asymmetrical questions: Why do students feel the need for feedback? Why is it important for teachers to create dialogue? Thereby we hope to be able to understand the nature of the interaction paradox and begin to consider how to deal with it in practice.

The paper is structured as follows. First, we review the literature on feedback and dialogue in education, focusing in particular on management education. Next, we describe the empirical setting of our study and the methods used for generating and 
analysing data. In our analysis of the empirical material, we then explore students' need for feedback and how teachers try to create dialogue. After these empirically derived reflections, we try to develop a model that can be used to reflect on feedback and dialogue in teaching and learning practice. Finally, we discuss our findings and present some implications of our analysis.

\section{Feedback and dialogue in (management) education}

From the teaching and learning literature we know that dialogue is more than simply a conversation; it is a set of practices - listening, respecting, suspending, voicing that, taken together, provide the potential to discover new insights and expand understandings (Bigelow et al., 2015; Laurillard, 2013). Effective dialogue is adaptive, discursive, interactive and reflective (Beech et al., 2010; Laurillard, 2013; Nicol, 2010).

Even though the idea that dialogue is essential for successful teaching and learning is widely accepted in the educational literature (Laurillard, 2013; Nicol, 2010; Palincsar, 1998; Vygotsky, 2012), many of the teaching activities that take place in the modern mass university are based on a transmission model, and the 'massification of higher education and the popularity of business schools have led to large class sizes that, ostensibly at least, do not lend themselves to relational approaches' (Anderson et al., 2017: 25). Instead teachers engage in one-way communication in large auditoriums: their monologues only occasionally interrupted by questions from students, small case discussions involving a subset of students or uneasy silences when the teacher asks a question and no one dares answer. This is unfortunate, because participatory learning activities can increase relational understanding and reflexive capabilities (Bissett \& Saunders, 2015), thus overcoming the narrow functionalist/technical focus sometimes associated with management education (Bissett \& Saunders, 2015; Srinivasan, 2007).

Effective dialogue should be adaptive by focusing on student's needs; discursive through two-way communication; interactive between actions and task goals and reflective on the feedback process (Nicol, 2010).

Feedback is a particularly important form of interaction from the students' perspective because it is seen to be able to help them learn how to perform better in exams. Feedback can be understood as a communication process where the student perceives and interprets feedback on their performance and where the teacher tries to create student-centred learning (Sadler, 2010). Feedback is information provided by teachers, peers, literature, self, etc., on student performance or understanding. Feedback is a consequence of performance and is provided on student performance (Hattie \& Timperley, 2007); the feedback will - hopefully - enhance the student's understanding (Hounsell et al. 2008) and thereby increase his or her level of performance. Effective feedback helps students ascertain what they grasp and what not, 
where their understanding is or is not good, and points to how to improve their performance (Ambrose et al., 2010).

Feedback is considered fundamental for effective learning because it clarifies the relation between present performance levels and learning objectives for both students and teachers. Yet, feedback is one of the most problematic aspects of student experience (Carless et al., 2011) and a contentious and confusing issue throughout higher education institutions (Boud \& Molloy, 2013).

Despite the considerable time and effort that teachers invest in providing student feedback, feedback seems to have limited impact when students do not get the idea, understand the meaning and/or lack the needed critical background knowledge regarding task agreement, quality and criteria (Sadler, 2010). Often students do not even bother to collect feedback on their examinations, which many universities are obliged to provide (Dysthe, 2011; Nicol, 2010; Sinclair \& Cleland, 2007). This creates frustrations for teachers who feel that their efforts are wasted and can have an impact on their future behaviour.

Although the literature generally finds feedback to be one of the most important elements in effective teaching and learning processes (Hattie \& Timperley, 2007; Havnes et al., 2012; Hounsell et al., 2008; Nicol, 2010; Weaver, 2006), scholars emphasize that the importance of classroom feedback is an under-researched area (Hattie \& Timperley, 2007), especially when it comes to students' perception of feedback (Weaver, 2006). While it is agreed that feedback is central, the predicament in providing satisfactory levels of feedback to students is a recognized and persistent problem in the modern mass university (Carless et al., 2011).

Often teachers' and students perceptions' of feedback diverge (Havnes et al., 2012), but what they do agree on is that feedback is often inefficient. Studies have revealed that students want feedback and that timely, personal, thorough, constructive, positive (or at least balanced) comments and criticism increase the likelihood of students embracing the feedback (Weaver, 2006). However, one study found that more than 40 per cent of the students questioned in a survey considered appropriate and timely feedback to be the weakest feature (Weaver, 2006). In student satisfaction surveys, feedback typically scores the lowest among all course features and students often call for more detailed feedback in a one-to-one setting (Nicol, 2010). Many teachers, meanwhile, claim that feedback is not working (Weaver, 2006) or that (more than half of) students do not collect their formative feedback (Sinclair \& Cleland, 2007). Therefore, it is perhaps not surprising to find studies showing that teachers speculate whether providing feedback is worthwhile, as it is time consuming to give when students are not using it anyway (Dysthe, 2011; Nicol, 2010). Hence, teachers may become discouraged (Sadler, 2010). 
When both students and teachers are dissatisfied with the feedback concept, it is a symptom of an impoverished dialogue (Nicol, 2010). The emergence of the mass university has meant that dialogue and one-to-one discussions between teacher and student are often squeezed out due to the increase in student numbers (Nicol, 2010). The result is inefficient formative assessment because timely and useful feedback is difficult when student numbers and hence teacher workload increase (Weaver, 2006). Nicol (2010) argues that only when a dialogue is reinstated in studentteacher interaction, can we expect feedback to be effective. Dialogic feedback is an interactive exchange where interpretations are shared, meanings negotiated and expectations clarified (Carless et al., 2011). For the teacher, dialogue is the most important part of the feedback process, while feedback is a primary element in formative assessment (Havnes et al., 2012; Sadler, 2010) when a teacher wants to align or re-align the learning process in order to improve students' understanding and help them become self-regulated learners (Carless, 2006).

Hattie and Timperley (2007) suggest that effective feedback should address three main questions: (1) Where am I heading/what are my goals? (2) What is the progress I made to reach my goal? (3) Where to next/what do I need to do to improve the process? These questions correspond to notions of 'feed up', 'feedback' and 'feed forward.' Ideally, both students and teachers should seek to answer all three questions.

It is not sufficient to focus only on performance levels. Additionally, feedback also has to reflect the learning objectives that define the desired level of performance. To be effective, feedback must be clear, purposeful, meaningful and related to students' prior knowledge so that they can make logical connections (Hattie \& Timperley, 2007). Feedback will be more relevant to students - and therefore more likely to be successful - if it is related to tests or assignments that have not yet been completed (Havnes et al., 2012).

\section{Empirical Setting and Methodology}

The empirical setting of this study is Aarhus BSS (Aarhus School of Business and Social Sciences), which is a part of Aarhus University. Aarhus BSS is one of the largest business schools in Europe and offers a wide range of degree programmes within fields such as economics, business, engineering, political science and communication at the Bachelor's, Master's and PhD levels.

For this paper, we focus on two MSc programmes offered by the Department of Management (MGMT): ITKO - an IT, communication and management programme taught in Danish - and cand.merc. (MSc in Economics and Business Administration). Under the cand.merc.-umbrella, we focus on six specializations that are all taught in English: Business Intelligence; Information Management; International Business; Marketing; Strategy, Organization \& Leadership and Innovation Management. These 
programmes have a shared set of learning goals, and according to the Academic Regulations (Board of Studies for Economics and Business Administration, 2015) this means that the graduate has acquired knowledge enabling him/her:

- To understand and consider knowledge pertaining to the various disciplines as well as to identify academic issues;

- To master the scientific methodologies and tools of the various disciplines as well as to master general skills associated with employment within the areas studied;

- To assess and choose among the scientific methodologies and tools of the various disciplines as well as to develop new analysis and solution models;

- To discuss professional and academic issues with specialists and laymen alike;

- To manage work and development situations that are complex, unpredictable and which require new solution models

These learning goals are difficult to achieve without having dialogue and interaction between teachers and students, with the latter needing feedback on their performance in order to reach these goals.

The size of the classes, in the relevant programmes, range from 15 to 350 students, where smaller classes of 15-40 students are infrequent and primarily used for electives; midsize classes of 60-180 students are normal on the master-level, and classes of 200-350 students might occur on methods courses shared by students in different cand.merc. specializations. Large class sizes are also frequent on the bachelor level programme. In other words, engaging in dialogue and feedback is often difficult for teachers as well as for students because of the big class sizes. The result is a situation that has been described as the 'Danish Wall of Silence' by foreign teachers when they start teaching at Aarhus BSS.

To explore the interaction paradox in this setting, we use a combination of quantitative and qualitative data. Quantitative data stem from Aarhus University's 2014 study environment survey (Jensen et al., 2014a, 2014b). The survey questionnaire was developed using concepts and experience gained in previous years. It was sent to directors of study and to the Aarhus University Student Council for consultation. Finally, it was tested in four focus groups, one for each of the four main academic areas at Aarhus University (Arts; Business and Social Sciences; Health; Science and Technology). Data were collected by means of an online questionnaire; in March 2014, all full-time students at Aarhus University received a link to the questionnaire by email. Data collection continued through mid-April 2014. The overall response rate was 40 per cent, with 13,647 students completing the survey. At 36 per cent, the response 
rate was slightly lower at Aarhus BSS, where 4,633 out of 12,375 students completed the survey.

Table 1: Study Environment Survey Response Rate

\begin{tabular}{|c|c|c|c|c|c|c|c|c|c|}
\hline & 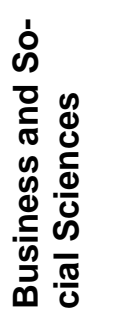 & $\begin{array}{l}\text { P } \\
\text { E}\end{array}$ & 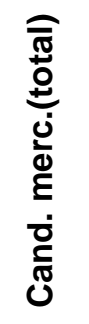 & 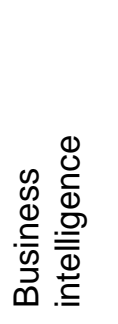 & 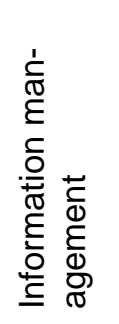 & 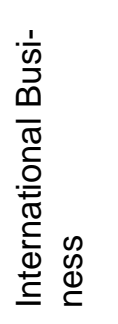 & 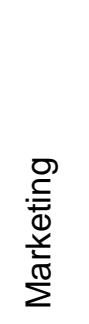 & 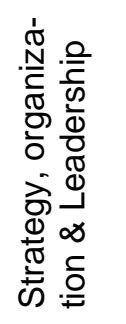 & 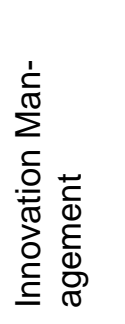 \\
\hline $\begin{array}{l}\text { Number of } \\
\text { answers }\end{array}$ & 4,633 & 86 & 204 & 11 & 13 & 48 & 56 & 48 & 28 \\
\hline Response rate & $36 \%$ & $47 \%$ & $34 \%$ & $30 \%$ & $31 \%$ & $36 \%$ & $30 \%$ & $38 \%$ & $41 \%$ \\
\hline
\end{tabular}

Source: Study Environment 2014 Aarhus University (Jensen et al., 2014a, 2014b)

Amongst a host of questions related to student wellbeing, the Study Environment survey included four questions related to feedback: 'I receive sufficient feedback regarding my performance during the semester'; 'The feedback I get on my work helps me improve my ways of learning and studying'; 'The feedback I get on my assignments/work clarifies things I had not fully comprehended'; and 'The possibility of receiving feedback regarding my academic performance is good'.

We use a subset of the data from the Study Environment survey that is relevant for the two MSc programmes at MGMT: ITKO and cand.merc. (see Table 1).

Data useful for understanding the background for the findings on students' demand for feedback was provided through the biannual focus group-like 'Student Panel meetings' with MSc students for each of the department's MSc programmes. The benefit of these group interviews is that they usually create dynamic interaction among the participants, which often leads to spontaneous and emotional discussions (Kvale, 1996). The purpose of Student Panels is to get student feedback on their general and overall impression of the content and teaching of the courses as well as the progression and relationship between the courses offered within each programme. Student Panels typically consist of 4-6 students depending on the number of students enrolled in the programme in question. Department members participating in the meetings include the Head of MSc programmes, the respective programme coordinator and the administrative secretary. At these meetings, students are specifically asked to address participative learning and whether they received feedback on their work during or after completion of the course. 
The data set on the teachers' wish for (more) dialogue was generated by means of an e-mail-based structured interview with teachers of the same students. This resulted in an idea catalogue with the purpose of promoting and facilitating knowledge exchange between lecturers across the various programmes. The teachers were asked to describe their experience of giving feedback and having dialogues in faceto-face as well as in an e-mail/online learning platform (Blackboard) setting. Eighteen out of 51 teachers answered the mail, which gives a response rate of 35 per cent. This data was subjected to two cycles of coding. The first cycle was open coding, where the answers were given descriptive codes (Miles \& Huberman, 1984) based on the topics that the teachers mentioned (Saldaña, 2013). The second cycle consisted of pattern coding, where first-cycle codes were grouped into more meaningful thematic codes (Miles \& Huberman, 1984; Saldaña, 2013).

In the following section, we address the results of the student survey in order to uncover the extent of the wish for feedback and why students feel they need (more) feedback. These findings will be related to the conceptual model developed later in this paper, where we argue that feedback is related to participative learning. Next, we address the students' understanding of participative learning based on the focus group discussions. We then present our results regarding the teachers' understanding of participative learning based on the structured e-mail-based interview.

\section{Results I: Students and their need for feedback}

\section{Students want more feedback}

The importance of receiving feedback for student learning is highlighted in the Study Environment survey (Jensen et al., 2014a). The results for BSS show that only a third of students agree that they get sufficient feedback regarding their efforts during the semester. This is highlighted by the following quote from the report:

The teachers should provide more feedback generally - in connection with exams and also on a daily basis. It is easy to feel unsure of yourself when you don't do as well as you expected, and you don't know exactly where it's going wrong. (Student, BSS) (Jensen et al., 2014a: 40).

The Study Environment survey dealt with students at Aarhus University in general. In this paper, we want to be more specific and therefore focus on the ITKO and cand.merc. programmes offered by our department. The six cand.merc. specializations offered by MGMT share the same structure: introductory courses in first semester, more advanced courses in the second semester, a third semester devoted to electives, exchange abroad and/or internships and a fourth semester, where students write their final thesis on a topic of their own choosing. Subject to approval by the study board, the individual courses are designed by the teachers involved and may therefore differ in terms of didactics, types of exams and other structural es- 
sentials. In other words, the amount and type of feedback provided in the individual courses in the MSc programmes differ widely.

This is also true in another of the department's MSc programmes: ITKO (IT, Communication and Organization). However, what is interesting in relation to the topic of this paper is that the ITKO programme has institutionalized feedback and participative learning. This gives us the opportunity to examine whether institutionalized feedback can play a role in solving the interaction paradox and the perceived lack of feedback. The ITKO programme specifically aims to develop students' ability to take part in project group work. Every semester, this type of participative learning is evaluated through a project exam where feedback is a compulsory part. These two study programmes are compared with all study programmes at the faculty of Business and Social Sciences at Aarhus University.

Figure 1: The Study Environment Study - Feedback

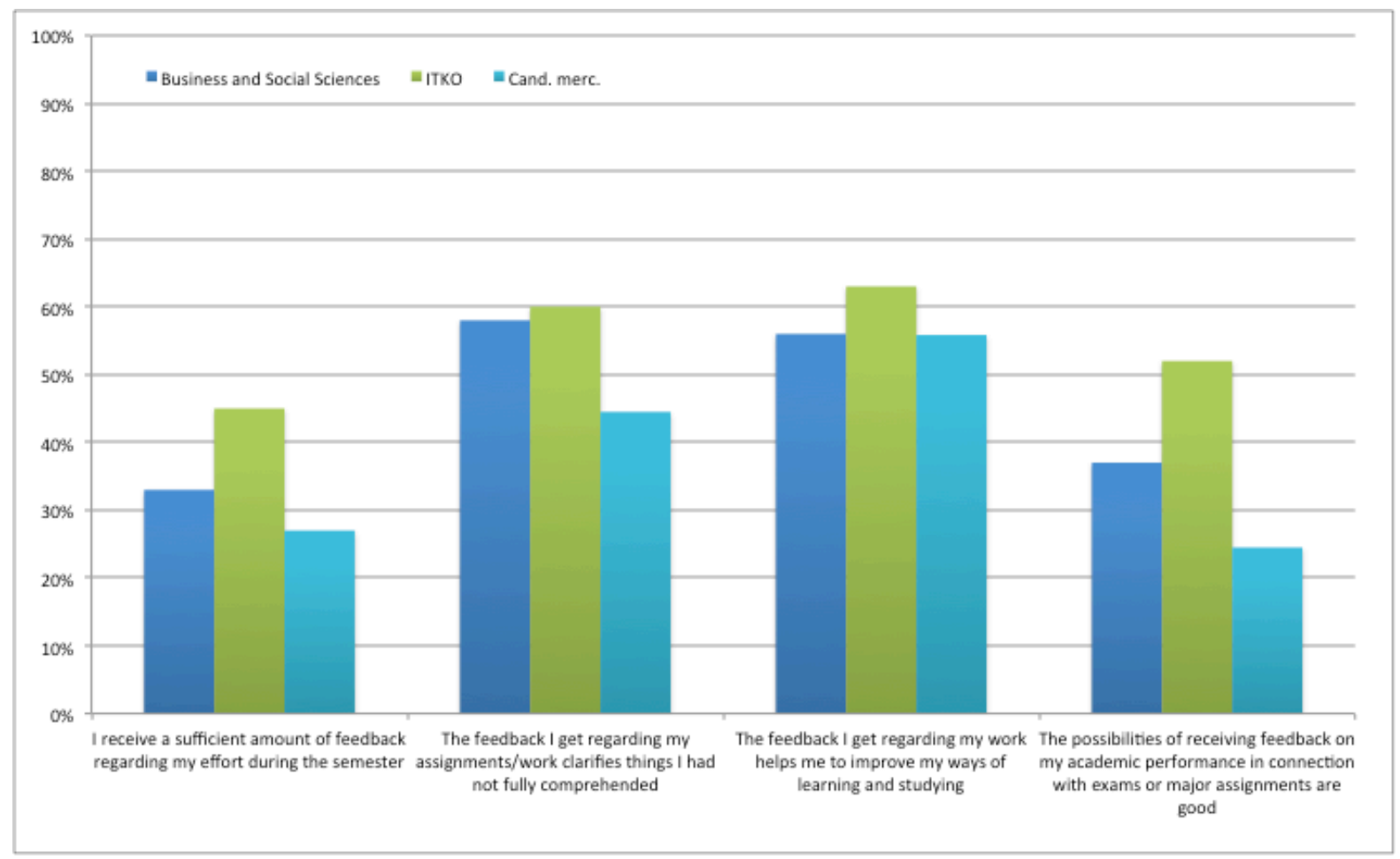

Source: Study Environment 2014 Aarhus University (Jensen et al., 2014a, 2014b)

Figure 1 illustrates the extent of the wish for feedback and why students feel the need for feedback. First of all, it is clear that the students want more feedback: less than half of the ITKO students and less than a quarter of the MSc students state that they receive sufficient feedback during the semester. Secondly, approximately half the students state that the feedback they get helps them identify gaps in their understanding and helps them improve their learning process. Third, students are not impressed with the quality and quantity of feedback they receive in connection with exams or large assignments. This is particularly obvious for the cand.merc. students, 
as less than a quarter consider the possibility of getting feedback on exams as being good. However, this is perhaps not surprising as students typically do not get individual feedback on their assignments or exam papers. ${ }^{1}$ Finally, Figure 1 shows that there is a big divide between the two MSc programmes when it comes to feedback on exams and assignments, with the two MSc programmes being on either side of the Aarhus BSS average.

A possible explanation for ITKO scoring higher and cand.merc. lower than the BSS average on feedback is that participative learning and feedback are institutionalized in the ITKO programme. This is clear when focus is on feedback given in connection with exams. However, it is surprising that the differences between the two MSc programmes are not bigger. We propose at least two possible explanations. First, while an institutionalized participative learning and feedback design means that students get more feedback, it also increases their expectations. Students seem to think that you can never get too much feedback; actually, the more feedback you get, the more you want. Second, the participative learning and feedback design of individual courses can play a significant role in the overall evaluation of the programmes. This is discussed in more detail in relation to the teachers' comments on how they apply participative learning.

The qualitative comments highlighted in the Study Environment survey report (Jensen et al., 2014a: 40) regarding feedback in relation to exams suggest that the lack of feedback is demotivating and that students need help to improve and to learn from their mistakes:

I think lack of feedback, especially after an exam, is a big problem! It is automatically assumed that we are top-motivated students. And, in general, we are, but a bad exam experience and/or a poor mark without further explanation is extremely demotivating." (Student, BSS)

${ }^{1}$ In 2017, the Study Board for Economics and Business Administration at Aarhus BSS decided that feedback must be provided for all written exams. The form is left to the individual teachers responsible for the course, and can thus be individual or collective, written or oral. 
Table 2. The Study Environment Study - Contact with teachers

\begin{tabular}{|c|c|c|c|c|c|c|c|c|c|}
\hline & 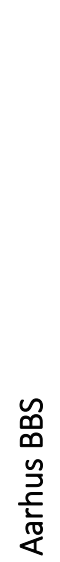 & 兰 & 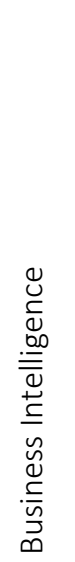 & 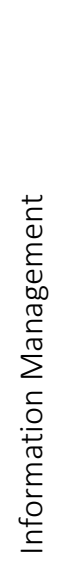 & 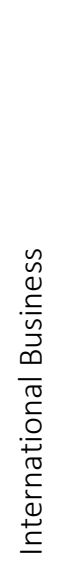 & 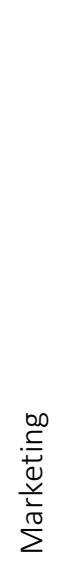 & 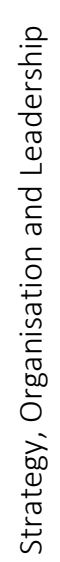 & 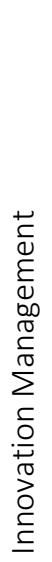 & 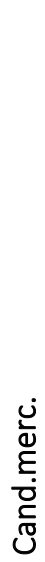 \\
\hline $\begin{array}{l}\text { It is easy to get in contact with most teachers } \\
\text { (Completely agree/most agree in per cent) }\end{array}$ & 58 & 60 & 73 & 92 & 60 & 59 & 61 & 78 & 67 \\
\hline $\begin{array}{l}\text { The teachers that I have been in contact with generally } \\
\text { seem interested in the students } \\
\text { (Completely agree/most agree in per cent) }\end{array}$ & 73 & 70 & 100 & 92 & 84 & 67 & 68 & 85 & 80 \\
\hline
\end{tabular}

Source: Study Environment 2014 Aarhus University (Jensen et al., 2014b)

In addition to feedback, the Study Environment survey included questions regarding more general interaction with teachers ('It is easy to get in contact with most teachers' and 'The teachers that I have been in contact with generally seem interested in the students'). Although it can be difficult to get in touch with teachers, teachers are seen as interested in students (see Table 2). These questions are very broad and open to interpretation of what they cover. In the focus groups we therefore explored what students understood by participative learning, interaction and dialogue.

\section{Students' understanding of participative learning}

When asked 'What is participative learning?' in the focus group interviews, the reflections of the participating students went in all directions regarding the types of, techniques for and the setting of feedback dialogues.

According to the students, productive participative learning types include workshops and role play as well as group work for large projects or case discussion sessions. Examples of unproductive interaction types include traditional lectures with Q\&A sessions: 'I don't like questions if it is about guessing' one student said, while another student stated that, 'We only participate because it is embarrassing for the teacher if nobody says anything'. To be more specific, many students commented on useful 
and not so useful techniques for creating dialogue. Clickers and other voting systems were seen as very productive, whereas many students saw student-teach-student sessions in particular as a waste of time. One student explained it this way:

Student-teach-student does not work when students present theoretical reviews. The ambitious student holds back with criticism [of other, not so ambitious students], it is a waste of time.

Furthermore, the setting created for dialogue was mentioned to be essential, especially if the assumption for interaction is that the student comes to classes because they perceive it to give greater value than staying at home studying. Another type of comment related to the setting is the length of sessions and the need for breaks. A student summarizes the setting as an important factor:

Four-hour lectures are generally too extensive, and when the teacher uses a participative learning strategy, people slope off.

The above reflections demonstrate that students recognize participative learning, if used and designed in the right way, as being productive for creating dialogue in class. In other words, these ideas for designing programmes and courses can create student activity to make feedback a natural part of the education.

\section{Results II: Teachers want dialogue}

The present analysis of teachers' understanding of participative learning is based on structured interviews conducted via e-mail. We first address why teachers find it important to create interaction and dialogue. Then, we discuss techniques that teachers have used successfully or unsuccessfully to create dialogue (at least in their understanding). Next, we focus on how to create a foundation for effective dialogue in participative learning settings and thereby feedback. We then focus on the barriers to the creation of such a foundation before, finally, discussing the criteria of success and the teachers' motivation for creating an efficient feedback culture.

\section{Dialogue and interaction are important!}

Regardless of what subjects they are teaching, all respondents consider interaction and dialogue with students to be important because it promotes student engagement, motivation, attention and ownership. In this way, interaction and dialogue are seen to have a positive impact on students' levels of performance.

Passively receiving information from lectures and PowerPoint presentations are often considered to be ineffective forms of learning. In contrast, active participation and interaction are seen as essential components of the learning process as they allow students to work with the subject matter and provide students with the opportunity to appropriate the vocabulary of the subject, i.e., to perform relative to the learning objectives. For instance, one respondent views it as important that students 
'get the opportunity to formulate their understandings and misunderstandings' by engaging in dialogue with teachers and fellow students. Interaction and dialogue are seen as especially important 'in fields where there are no definite answers'.

Furthermore, dialogue and interaction give teachers valuable information about how they are performing as teachers and to adjust the content and level of their teaching to the group of students they are facing. By allowing students to use what they are being taught, interaction and dialogue facilitate the feedback process and allow teachers (and sometimes fellow students) to provide targeted feedback on what is (not) understood, where the understanding is (not) good and how students can do better. Interaction and dialogue are also seen to enable students to utilise their own knowledge and perspectives. This is especially the case in part-time programmes with students from business. However, teachers often find that it is a struggle to engage students in dialogical activities and therefore can be unsure of how they are doing as teachers.

\section{Successful initiatives}

Respondents claim to have successfully used a wide range of activities to generate interaction and dialogue in class and in virtual learning environments, thus giving students the opportunity to perform and providing teachers with something to give feedback on. Activities that respondents argue have been used successfully include simulations, case discussions, seminars, workshops, company visits, supervision of project groups, group discussions (for instance using the think/pair/share approach), online discussions, planned class discussions and discussions of previous exam assignments. For instance, one teacher asks students to present scientific papers and cases in class in order to make them familiar with what is required when later writing scientific papers and in exam situations. The teacher considers this to be a successful practice, but it is perhaps relevant to bear in mind that student-teach-student was not considered useful by students in the study panel for presentations of theoretical issues.

Other teachers stress the importance of being available for answering questions in breaks (or after class), as the teacher can follow up on these questions after the break or in the following lecture. Dialogue - whether in class or during breaks - is important for adjusting the teaching level, for instance to ensure that teachers balance the complexity of questions so that students will not find questions too difficult and not too easy either. Furthermore, some teachers provide written feedback on assignments and exams, although this is hard to practice when teaching large classes. Using 10 minutes to give individual feedback to a normal class of $60-80$ students easily makes for a good long day of work. 


\section{Unsuccessful initiatives}

Sometimes activities that were successful in one class turn out unsuccessful in another. When discussing why attempts to foster dialogue in interaction fail, teachers describe a variety of barriers. Many of these are related to the contextual factors, such as 'auditoriums are not suitable for dialogue' or that classes are too big. Some teachers also point to (at least some) students being immature and some who are poorly motivated and come unprepared. Some teachers have even experienced students complaining about being disturbed while on Facebook, and some respondents mention that certain students 'attend classes only sporadically'.

While dialogue and interaction are considered important, several respondents note that the current favoured model for teaching at Aarhus BSS (large classes; one final written exam) works against providing students with detailed feedback on their performance. Not least the growing number of written exams is seen as reducing the opportunity for providing feedback. Some respondents also point out that not all students take advantage of the opportunity for interaction and dialogue provided by teachers, and it is acknowledged that there will always be a group of students that do not feel comfortable participating in class. In this connection, it is also mentioned that the atmosphere differs across classes, and that the atmosphere of a particular class can either be conducive or unfavourable to students engaging in dialogue and interaction. Some teachers argue that this is because 'bachelor students are trained to be passive'. The context that this statement should be understood in was described earlier when presenting the empirical setting - Aarhus BSS. Bachelor students are often in classes of 200-350 students for lectures, which is not a setting conducive to participative learning activities.

Respondents have mixed experiences with student-teach-student activities (as do students, as we saw above). One respondent commented that 'some students are really pleased with this [activity], but the majority can't be bothered'. According to this respondent, these students have different explanations as to why they dislike this activity: the groups presenting are not prepared; that they are uncomfortable presenting in front of their peers; that it is time-consuming, and so on. The respondent speculates that these are just convenient excuses.

These reasons for low student performance levels are supplemented with many respondents suggesting that barriers could be avoided by formulating clear learning objectives: interaction should be stated as a requirement to counter the problem that 'we cannot require attendance' or that 'students want tutoring only', which underlines that participative learning requires participation. An example of a failed attempt to engage in dialogue and interaction was given by a teacher who said that 'when I addressed the class with questions and/or tried to initiate a discussion [by] allocating substantial time to work on a case study (about 45 minutes), up to a third 
of the class left'. Another teacher said that, 'students are reluctant to report back to the class/whole group after short group discussions'. When simple questions are asked in class, often there is no feedback because 'students are not used to being asked and fear giving the wrong answer', which ironically ends up in a situation where 'students think they did not get enough feedback on case work'. An alternative explanation is that students perceive the questions as too simple.

The physical settings should also promote interaction and dialogue, but the setup of many classrooms is seen to favour one-way teaching with fixed-seat auditoriums, and the number of students is often too high for traditional student-teacher dialogue. Also, it is seen as an impediment that students' unwillingness to participate cannot be reflected in their grades. Teachers view these kinds of barriers as a challenge to the establishment of interaction and dialogues.

\section{Requirements for successful dialogue}

Successful participative learning occurs when students are motivated and (inter)active and their performance is aligned with clear participative learning objectives, which help students to receive and use feedback to improve their learning. For attempts to foster dialogue and interaction to be successful in improving student performance levels, engaged teachers and motivated students are required. 'Real' students are, therefore, argued to be those '[motivated] students who respond to the offer of such initiatives and work together with the teacher in an interactive manner'. In other words, some respondents equate good students with good performance. To some extent at least, blaming students for being lazy and immature can seem to be a convenient excuse for teachers rationalizing why they do not engage in interactive practices such as providing feedback.

With regard to teachers, good teachers are seen by our respondents as being experienced in teaching and having developed improvization abilities; they should also be able and 'willing to engage in such initiatives' and they should know that 'learning objectives should be expressed' along with 'sound explanations of why and how' they are 'aligned with the grading system'. In general, the key success criteria include a feedback process that 'trains students to receive feedback that will help them learn, not [just] pass the exam'. This process takes more time than classic lecturing and requires that the parties trust each other.

\section{Student-teacher interaction - a conceptual model for improving feedback}

In the preceding sections, we have discussed student and teacher perspectives on interaction, dialogue and feedback in learning settings at Aarhus BSS. From the student perspective, feedback is seen as particularly important. In fact, students' demand for feedback seems to be insatiable. According to the data from teachers, participative learning is constituted by the students' formulation of understandings and 
misunderstandings, which is in alignment with the objectives of participative learning through interaction and dialogues about what was (not) understood, where (mis)understandings are found and how to improve understanding and performance. Students doing exercises and activities facilitate feedback, which can be oral or written, in- or outside the class or in breaks. Learning objectives must be operationalized to enable this feedback.

Table 3 presents a summary of our finding regarding the teachers' ideas on how to improve feedback, interaction and dialogue in a participative learning setting.

Table 3: Teachers' idea catalogue

\begin{tabular}{|l|l|l|l|}
\hline Facilitators & \multicolumn{1}{|c|}{$\begin{array}{c}\text { Goal directed } \\
\text { practice }\end{array}$} & $\begin{array}{c}\text { Participative } \\
\text { learning elements }\end{array}$ & Targeted feedback \\
& $\begin{array}{l}\text { Learning objectives } \\
\text { are operationalized } \\
\text { to facilitate the right } \\
\text { level of questions } \\
\text { asked and the feed- } \\
\text { back given }\end{array}$ & $\begin{array}{l}\text { Exercises (simula- } \\
\text { tions, case studies, } \\
\text { seminars, workshops) } \\
\text { and activities (com- } \\
\text { pany visits, supervi- } \\
\text { sion of project } \\
\text { groups, group talks, } \\
\text { online and class dis- } \\
\text { cussions) }\end{array}$ & $\begin{array}{l}\text { Feedback on student } \\
\text { exercises and activi- } \\
\text { ties in class, in writing } \\
\text { or in the breaks be- } \\
\text { tween lectures. }\end{array}$ \\
\hline Barriers & $\begin{array}{l}\text { When the desired } \\
\text { level of performance } \\
\text { is not described in a } \\
\text { balanced way and } \\
\text { when it is not aligned } \\
\text { with grading }\end{array}$ & $\begin{array}{l}\text { Substandard audito- } \\
\text { riums, too large clas- } \\
\text { ses, low-level student } \\
\text { participation and no } \\
\text { grading on participa- } \\
\text { tion }\end{array}$ & $\begin{array}{l}\text { Students and teacher } \\
\text { are reluctant to inter- } \\
\text { act resulting in non- } \\
\text { feedback dialogue. }\end{array}$ \\
\hline Key success factors & $\begin{array}{l}\text { Learning objectives } \\
\text { should be expressed } \\
\text { explaining properly } \\
\text { why and how they } \\
\text { are aligned with the } \\
\text { grading system }\end{array}$ & $\begin{array}{l}\text { Motivated and inter- } \\
\text { active-minded stu- } \\
\text { dents }\end{array}$ & $\begin{array}{l}\text { Train students to } \\
\text { receive feedback that } \\
\text { will help them learn }\end{array}$ \\
\hline
\end{tabular}

Although the above list is valuable as inspiration for the individual teacher, we think this is not enough in order to design institutionalized feedback practices. We therefore outline a model that can help design feedback practices both at the course and programme levels.

Figure 2 is based on the main insights from our analysis and key points from literature referenced earlier. It illustrates that feedback is a dialogical method for aligning 
learning objectives and performance levels through a focus on performance level issues and how to solve them.

The model illustrates that providing students with targeted feedback takes its starting point in actual student activities characterized by a certain performance level seen in relation to the learning objectives for this activity (Arrow 1: Goal-directed practice).

The teacher can then evaluate to what extent the student has met the learning objectives and provide targeted feedback (Arrow 2: Targeted feedback). Feedback can be provided on the level of performance (e.g., on the level of understanding, with a focus on what is understood and what is not) and where the performance is good or could be better (e.g., where understanding is good or lacking). Feedback should also provide the student with suggestions on how to improve his/her performance. In other words, it is impossible to provide feedback without the student being an active participant in the learning process; creating shared classroom discussions is difficult and it always requires two active parties to engage in communication (Havnes et al., 2012).

Figure 2: Student - teacher interaction

\section{Goal-directed practice}

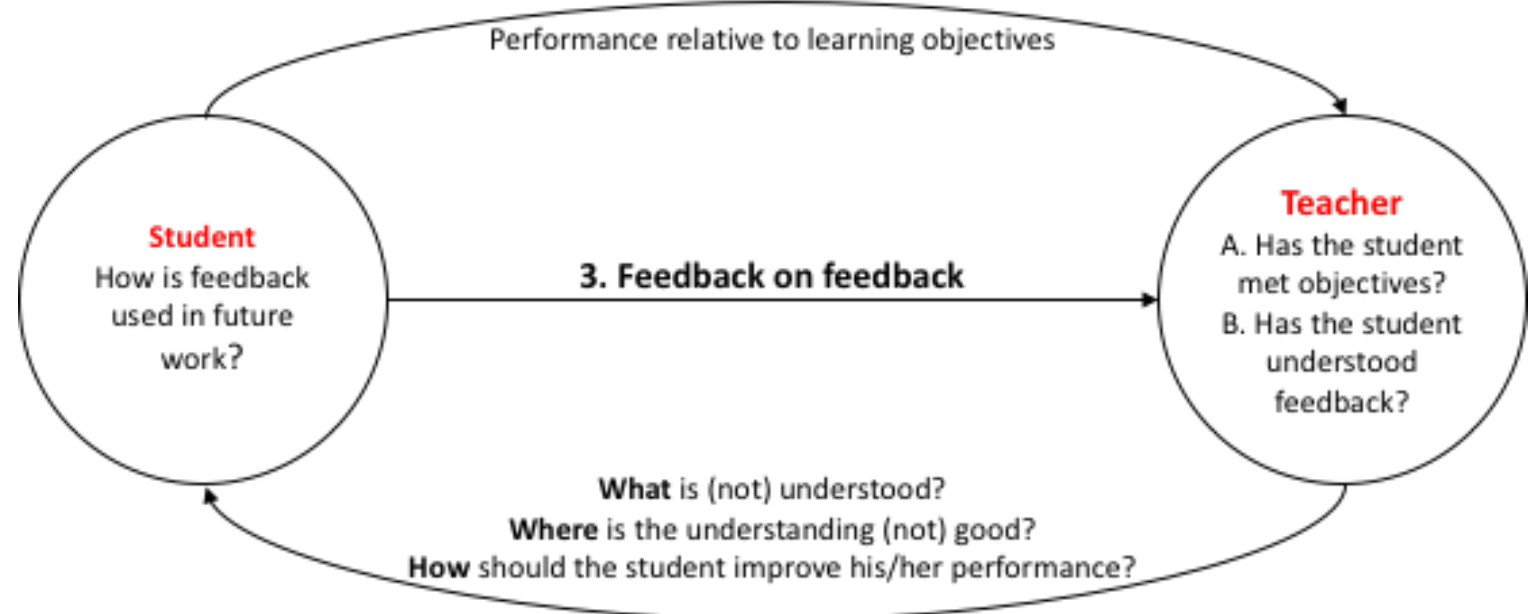

2. Targeted feedback

Source: Inspired by Ambrose et al. (2010).

Given that feedback should be dialogical, the student can then provide the teacher with feedback (Arrow 3: Feedback on feedback), who can then evaluate whether the original feedback was successful and provide more feedback if required. The extent to which students use feedback can be evaluated once a new performance has been delivered. 
The model thus illustrates that feedback involves teachers' and/or students' giving and receiving feedback (Hattie \& Timperley, 2007) in a cyclical process (Nicol, 2010), both with respect to course work and exams (Hounsell et al., 2008). Ideally feedback should involve two-stage assignments where the student will use the feedback in the first stage to improve the performance and/or quality of the work for the second stage submission (Carless et al., 2011). If revision of the work is unfeasible (as will often be the case in the mass university), the feedback to the student should focus more on what to do in the future (Dysthe, 2011).

As our results showed, students are critical of certain types of activities (not least student-teach-student) and there are structural factors (large class sizes, physical layout of class room) that can make it difficult to engage students in dialogical activities. Thus, teachers have to think carefully about designing courses and activities in order to encourage student performance.

If examination is seen as part of the learning process, feedback on examinations can be relevant. This is the case in our programmes, where we have this year made it mandatory to provide feedback on all written exams while leaving the form (written or oral, individual or collective) up to the individual course responsible.

The focus on student performance means that learning objectives should be clear so that students can use them to guide their activities and so that they can be used in the feedback process. To conclude, establishing a feedback culture requires appropriate learning objectives and that both teacher and students are active.

\section{Discussion and implications}

In this paper, we have argued that both students and teachers call for more dialogue, but that modern management education faces an interaction paradox as both students and teachers are left wanting. Interaction, dialogue and feedback between students and teachers are crucial for learning and hence should take centre stage in the development of individual courses and educational programmes.

From the Study Environment survey, we know that the students want more feedback in order to clarify their understandings and misunderstandings and to get help to improve their learning process. In our student panel interviews we found that students recognize that they have to be active in order to create a participative learning setting where interaction and dialogue drive the feedback processes. However, this requires that exercises and activities are seen as productive and meaningful.

Tackling these issues is a challenge for individual teachers, who have to think carefully about how they can incorporate activities that stimulate dialogue and are seen as meaningful by students and provide opportunities for giving feedback into their teaching. Teachers can adopt learning objectives for their respective courses that define what is meaningful in the given context, where the focus is on the creation of 
a participative learning atmosphere and where the objectives are operationalized to facilitate appropriate questioning and feedback. This means that the learning objectives should identify the desired level of performance and contain sound explanations of why and how this is evaluated. The performance of students relates to their ability to formulate their understandings and misunderstandings when working with exercises (simulations, case studies, seminars, workshops, etc.) and for the students who participate in activities to find them relevant (company visits, supervision of project groups, group talks, online and class discussions). It is also important that individual teachers provide feedback when students can still benefit from it to improve their performance, i.e. before the exam (cf. Ambrose et al., 2010; Hattie \& Timperley, 2007; Weaver, 2006).

Dialogue and feedback is not only important for how students perform. It also impacts how teachers perform and ultimately their well-being. When dialogue is lacking in the class room, it is difficult for teachers to develop an appreciation of whether they are successful in their endeavours - are students developing the knowledge, competences and skills they are supposed to, or does the teacher need to take a different approach? It is also a source of frustration for teachers if they fail in engaging students in interaction and dialogue. Interactive, participative learning based on dialogue and feedback tends to be encouraged by university educational development teams, but can result in 'a misalignment between the responsibilities and job demands and the way institutions govern people in such roles' that has been shown to affect the well-being of teachers by creating expectations that teachers have difficulties meeting (Franco-Santos, et al., 2017: 1). That the students often do not collect the feedback on examinations, which many universities are obliged to provide, (Dysthe, 2011; Nicol, 2010; Sinclair \& Cleland, 2007) can also be a source of frustration for the teachers and have a negative impact on academic well-being.

Individual teachers cannot solve the interaction paradox on their own. It is important that universities create an institutional setup that is conducive to providing feedback and fostering dialogue between students and teachers in order to stimulate student learning and facilitate academic wellbeing. In this connection, it is important for institutions to think about what can be done to encourage teachers to engage in dialogical activities such as providing feedback to students. At the Department of Management at Aarhus BSS, for instance, the system has been revised to include a teaching norm for giving feedback to students, whether on exams or during the semester. Providing feedback hence does not have to be con amore. This facilitates meeting the requirement for feedback on exams that was recently passed by the study board. Our results suggest that students react positively to institutionalized feedback on exams, but also that student expectations increase.

There are also challenges that are more difficult to overcome, at least in the short run, including auditoriums that are more suitable for one-way teaching, classes with 
large numbers of students and limited possibilities for grading on participation. If these barriers are too high, the result is non-feedback dialogues, where dialogue is only about why students and teachers are reluctant to interact.

Teachers and universities can do a lot to improve dialogue, but there is also a literature suggesting that there are individual-level reasons on the part of students that can explain why they are not participating actively in dialogical activities, that also should be taken into account. One is that business students have become more narcissistic, with current students being part of 'Generation Me' (Twenge, 2014). Studies indicate that narcissism levels are increasing and are particularly high in business students (Twenge, et al., 2008). Students high in narcissism display 'a pervasive pattern of grandiosity, self-focus and self-importance' that is incompatible with collaborative learning techniques such as in-class, group-based instructional methods (Bergman, et al., 2010) and critical reflection (Tomkins \& Ulus, 2015). Narcissistic students suffer from a range of interpersonal deficits; are likely to be hypersensitive to evaluation and potentially negative feedback; show a sense of entitlement; and have difficulty engaging in learning processes as they find it difficult to admit that others may be more knowledgeable than they are (Beck, et al., 2015; Bergman et al., 2010). Bergman et al. (2010) note that managing productive classroom discussions, presentations, debates and other learning-centred activities represent challenges for management faculty.

Another potential explanation for the interaction paradox is that typical business students, aged 18-25 years, are in a life development phase referred to as emerging adulthood (Arnett, 2000; Dachner \& Polin, 2016). During this stage of development, young adults are distinctly different from mature adults demographically, cognitively, emotionally and socially (Arnett, 2000). This has implications for teaching and learning. Dachner and Polin (2016) therefore argue that management teachers should recognize that the majority of their students are in a state of transition. Among other things, teachers should take into account that the identities of emerging adult students are becoming more complex; that students are not yet intrinsically motivated to learn; have high information requirements in relation to what, why and how they want to learn; may not have sufficient work and life experience to benefit from only in-class application; and may not have a well-developed, problemcentred mindset to immediately seek to apply what is learned (Dachner \& Polin, 2016).

Pedagogical initiatives at Danish universities mainly have focused on improving the skills and competences of teachers, but perhaps it would also be interesting for pedagogical units to help students develop skills for participating in dialogical learning activities and working with feedback. In this connection, it would be relevant to replicate some of the referenced studies within a Danish context. We need further re- 
search to uncover if good feedback merely leads to a demand for more feedback or whether it is a question of the frequency of feedback. More research regarding what students understand by feedback and dialogue, including whether they realize when teachers are offering feedback, would also be welcome.

Dialogue between students and teachers in management education, is a shared responsibility. It requires that students are willing to engage in participatory learning activities and that teachers are able to make these meaningful. It is up to study boards and directors of studies to create institutional frameworks that are conducive to and reward dialogue. This will improve learning and make both studying and teaching more rewarding. It is our hope that the model we propose can be valuable in these discussions about dialogue and feedback between students and teachers.

\section{References}

Ambrose, SA, Bridges, MW, DiPietro, M, Lovett, MC \& Norman, MK. 2010. How learning works: Seven research-based principles for smart teaching: John Wiley \& Sons.

Anderson, L, Ellwood, P \& Coleman, C. 2017. "The impactful academic: Relational management education as an intervention for impact." British Journal of Management 28.1: 14-28.

Arnett, J J. 2000. "Emerging adulthood: A theory of development from the late teens through the twenties." American Psychologist 55.5: 469.

Beck, AT, Davis, DD \& Freeman, A. 2015. Cognitive therapy of personality disorders: Guilford Publications.

Beech, N, Maclntosh, R \& MacLean, D. 2010. "Dialogues between academics and practitioners: The role of generative dialogic encounters." Organization Studies 31.9-10: 1341-1367.

Bergman, JZ, Westerman, JW \& Daly, JP. 2010. "Narcissism in management education." Academy of Management Learning \& Education 9.1: 119-131.

Bigelow, B, Elsass, P \& Arndt, M. 2015. "Dialogue in the graduate management classroom: Learning from diversity." The International Journal of Management Education 13.1: 48-56.

Bissett, N \& Saunders, S. 2015. "Criticality and collegiality: A method for humanizing everyday practice?" Journal of Management Education 39.5: 597-625.

Board of Studies for Economics and Business Administration. 2015. Academic Regulations for Master's degree Programme in Economics and Business Administration at Aarhus University. Aarhus BSS Aarhus University.

Boud, D \& Molloy, E. 2013. "Rethinking models of feedback for learning: the challenge of design." Assessment \& Evaluation in Higher Education 38.6: 698-712. 
Carless, D. 2006. "Differing perceptions in the feedback process." Studies in higher education 31.2: 219-233.

Carless, D, Salter, D, Yang, M \& Lam, J. 2011." Developing sustainable feedback practices." Studies in higher education 36.4: 395-407.

Dachner, AM \& Polin, B. 2016. "A systematic approach to educating the emerging adult learner in undergraduate management courses." Journal of Management Education 40.2: 121-151.

Dysthe, O. 2011. "'What is the purpose of feedback when revision is not expected?'A case study of feedback quality and study design in a first year master's programme." Journal of Academic Writing 1.1: 135-142.

Franco-Santos, M, Nalick, M, Rivera-Torres, P \& Gomez-Mejia, L. 2017. "Governance and well-being in academia: Negative consequences of applying an agency theory logic in higher education." British Journal of Management 28: 711-730.

Hattie, J \& Timperley, H. 2007. "The power of feedback." Review of Educational Research 77.1: 81-112.

Havnes, A, Smith, K, Dysthe, O \& Ludvigsen, K. 2012. "Formative assessment and feedback: Making learning visible." Studies in Educational Evaluation 38.1: 21-27.

Hounsell, D, McCune, V, Hounsell, J \& Litjens, J. 2008. "The quality of guidance and feedback to students." Higher Education Research \& Development 27.1: 55-67.

Jensen, TK, Herrmann, KJ, Bager-Elsborg, A, Nielsen, I, Hansen, IB \& Nielsen, RB. 2014a. Study Environment 2014 Aarhus University (Vol. 1). Aarhus, Denmark: Aarhus University.

Jensen, TK, Herrmann, KJ, Bager-Elsborg, A, Nielsen, I, Hansen, IB \& Nielsen, RB. 2014b. Undersøgelse af studiemiljøet ved Aarhus Universitet (Vol. 3: Studiemiljøtal for uddannelser ved School of Business and Social Sciences). Aarhus, Danmark: Aarhus Universitet.

Kvale, S. 1996. Interviews: An Introduction to Qualitative Research Interviewing. Thousand Oaks, Calif.: Sage Publications.

Laurillard, D. 2013. Rethinking University Teaching: A Conversational Framework for the Effective Use of Learning Technologies. Routledge.

Miles, MB \& Huberman, AM. 1984. Qualitative Data Analysis - A sourcebook of new Methods. Sage Publications.

Nicol, D. 2010. "From monologue to dialogue: Improving written feedback processes in mass higher education." Assessment \& Evaluation in Higher Education 35.5: 501-517. 
Palincsar, A S. 1998. "Social constructivist perspectives on teaching and learning." Annual Review of Psychology 49.1: 345-375.

Sadler, DR. 2010. "Beyond feedback: Developing student capability in complex appraisal." Assessment \& Evaluation in Higher Education 35.5: 535-550.

Saldaña, J. 2013. The Coding Manual for Qualitative Researchers: Sage.

Sinclair, HK \& Cleland, JA. 2007. "Undergraduate medical students: Who seeks formative feedback?" Medical Education 41.6: 580-582.

Srinivasan, SK. 2007. "Drucker: On learning (to learn) management." Vikalpa 32.4: 112.

Tomkins, L \& Ulus, E. 2015. "Is narcissism undermining critical reflection in our business schools?" Academy of Management Learning \& Education 14.4: 595-606.

Twenge, JM. 2014. Generation Me: Why Today's Young Americans are More Confident, Assertive, Entitled - And More Miserable Than Ever Before. Revised and Updated. Simon and Schuster.

Twenge, JM, Konrath, S, Foster, JD, Campbell, WK \& Bushman, BJ. 2008. "Egos inflating over time: A cross-temporal meta-analysis of the Narcissistic Personality Inventory." Journal of Personality 76.4: 875-902.

Vygotsky, LS. 2012. Thought and Language. Cambridge, MA: MIT press.

Weaver, MR. 2006. "Do students value feedback? Student perceptions of tutors' written responses." Assessment \& Evaluation in Higher Education 31.3: 379-394. 